\title{
New Zealand media camouflage political lobbying
}

\begin{abstract}
Political lobbyists are a part of government decision-making processes, and many countries have stringent regulations to ensure their activities are somewhat transparent, especially as some use ethically questionable tactics. In New Zealand, however, there are no similar legislative regulations, and lobbyists can stay undetected while trying to influence policymaking. More concerning, however, is that the results of this study indicates that lobbyists are also able to skirt around scrutiny in New Zealand media because of current journalism practices. This research's content analysis indicates the media neglects to identify lobby organisations, thereby allowing them to operate without detection of their agenda, leaving the public unaware of who is influencing decision makers.
\end{abstract}

Keywords: advocacy, agenda setting, astroturfing, content analysis, framing, lobbying, New Zealand, political journalism, public opinion, transparency

\section{CATHERINE STRONG and FRAN TYLER \\ Massey University, Wellington}

\section{Introduction}

N DEMOCRATIC countries there is growing concern of lobbyists who try to work below the radar and ensure the public is unaware of who and what are influencing legislative decisions. As outlined in the literature review below, a growing concern is 'astroturfing' whereby the lobby group creates benign-looking spokespeople or groups to put forward their case, and the real clients are able to stay concealed in the background (Hager, 2014; Fitzpatrick \& Palenchar, 2006; Stauber \& Rampton, 2004). It is challenging for media to investigate the foundation of such groups to expose them as faux. It would seem easy, however, to identify lobby groups as such when they are the ones speaking out in the media, but this study found this was not so. This research initially questioned if journalists identified political pressure groups accurately as 'lobbyists' or used a more palatable label such as 'advocacy', 'government relations', or 'single interest' group. The results were surprising in that the media camouflaged the lobby groups by not identifying them at all, using no labels to identify them. 
A lack of academic research into lobbying in New Zealand meant that much background information for this study is from previous news stories and a handful of textbooks. Many of the news stories focused on one-off examples like Members of Parliament accepting perks from lobbyists, such as tickets to Rugby World Cup games, or lobbyists being issued coveted Parliamentary access swipe cards. In 2014, however, investigative journalist Nicky Hager published the book Dirty Politics based on a series of leaked emails, which described a covert and manipulative relationship between lobbyists, the government and prominent right-wing bloggers. The information in Hager's book sparked our study on the visibility of lobbyist's activities. This article explores how the New Zealand media identify lobbying groups, which would ensure news audiences are aware of the agenda behind a group's media stance or statement.

\section{Literature review}

New Zealand's Parliament does not have an official definition for lobbying, however the two-decade old Kent handbook on lobbying in New Zealand (1998) describes lobbying as: 'the modern communication art of ensuring your opinions are heard by decision makers' (p. 6); and the UK Public Affairs council expands the definition to explain that it is attempting to influence 'government, parliament, the devolved legislatures or administrations, regional or local government or other public bodies in any matter within their competence' (UKPAC, 2014). Simply put, the objective of lobbying is mobilising public opinion to create pressure on decision makers for competitive advantage or commercial gain (Harris, 2002).

While lobbyists sometimes play an important role in the decision-making process by alerting politicians to the viewpoint of some stakeholders, they 'carry a negative connotation in the public' (Greisser, 2013, p. 36), and the tactics used by some practitioners has brought them into disrepute publically (Berg, 2012; Thomson \& John, 2007; Zetter, 2008). Lobbyists are generally mistrusted by the public and that there is a view that they 'in some way distort the political process', a reputation blemished when it appears that well-funded groups can hire lobbyists to pressure policymakers to consider their viewpoint more than those with less of a voice (Thomson \& John, 2007, p. 4). As a result, many political actors and public servants are reluctant to admit that they have contact with lobbyists, or that they receive valuable and useful advice and briefings from them (ibid). This poor reputation led to the American association for lobbyists to change its name in 2014 to 'The Association of Government Relations Professionals' (Yaeger, 2013).

\section{Transparency in New Zealand}

New Zealand has no formal register of lobbyists, unlike a number of other 
Western democracies such as Australia, Canada, France, Germany, Ireland, Lithuania, Netherlands, Poland and the United States, which have legislation that control lobbying activity among public officials and ensure it is visible (Krsmanovic, D. 2014; Malone, 2004). In 2012, a Green Party's attempt to develop a register and improve transparency was thwarted when Parliament voted down the Lobbying Disclosure Bill, which outlined:

There is no public scrutiny of the activities of people who are paid to lobby parliamentarians, their staff, or public servants. Nor is there any code of ethics. This means there is no way of knowing who is engaged in the lobbying process, who is lobbying whom, and for what purpose (p. 1).

The bill would have established a register of lobbyists and required them to comply with a code of conduct. It also would have required them to file annual returns with the Auditor-General. The main reason for the bill's failure was the difficulty in defining what a lobbyist was, as well as the proposed law would have captured not just professional lobbyists, but anyone wanting to contact their MP about any issue (Crang, 2013).

Without mandatory registration it is difficult to easily identify who is actively involved in lobbying MPs. Some idea can be gleaned from the 105 submissions to the Lobbying Disclosure Bill (Parliament, 2013). Among the industries opposing legislation to register lobbyists were: advertising, brewing, energy, farming, financial services, banking, horticulture, hospitality, tertiary education, fast food, meat, forestry, accounting, law, pork, retailers, winegrowers, newspaper publishing, fishing, retirement villages, unions and, not surprisingly, public relations.

Besides the difficulty in identifying who is lobbying MPs, it is also difficult to assess how many there are. A 2004 report on lobbying by the National University of Ireland's Institute of Public Administration found there was 'very little literature on this subject in New Zealand at the moment' (Malone, 2004, p. 17). The only hint is based on anecdotal evidence, such as from former Cabinet Minister Trevor Mallard who stated that there was an increasing trend in organisations using lobbyists, and he predicted it would grow moreso. 'Lobbying as a practice and a discipline is going to get more sophisticated and more common' (Mallard, 2003, $\S 63)$. Ten years after Mallard's prediction, this growth was evident when the number of lobbyists granted access cards to enter Parliament buildings doubled, to 25 (Young, 2013). Another indication of the growth may be seen in the expansion of the closely-related public relations industry. Since the 1940s, the number of public relations practitioners has increased markedly (Hager, 2012). There are now more than 1350 members of New Zealand's Public Relations Institute, however there are many more who are not members (PRINZ, 2017).

Another indication of the number of lobbyists is to look to other Western 
democracies. In Australia, there were 597 registered lobbyists representing 1735 clients in 2016 (Australian Government Department of Prime Minister and Cabinet, 2017). This register excludes lobbyists working for charities, religious groups and NGOs, so the total figure is estimated to be more than 1000 active lobbyists working in Canberra (Hogan et al., 2011). In the USA there were 11,166 registered lobbyists in 2016, with businesses spending more than US\$3 billion each year on the activity (Center for Responsive Politics, 2017). The real number, however, is estimated to be 100,000 lobbyists and $\$ 9$ billion annual spending, as the industry is finding new ways to keep its activities private (Fang, 2014). According to an investigation by The Nation news magazine (ibid), lobbyists have found legislative loopholes to let them escape the registration list, and lobbying in America is going 'underground' so as to be invisible (§8). Furthermore, lobbyists are employing secret tactics, such as 'the development of increasingly sophisticated strategies that enlist third-party validators and create faux-grassroots campaigns', which hide their real identity and motives (§9).

\section{New Zealand lobbying tactics}

The scene is similar in New Zealand, where success in public relations and lobbying occurs when the public is not aware of it happening or who is responsible for it, according to independent investigative journalist and author Nicky Hager who has written a number of books about New Zealand politics where lobbyists played a part (Hager, 2014). The common practice of using third-person groups to influence lawmakers is also verified by New Zealand Public Relations And Communications Management textbook, which outlines the tactics used by lobbyists as 'direct' when meeting with officials and making public submissions to government, and 'indirect', when influencing public opinions by email writing campaigns, publicity stunts, and encouraging friendly MPs to ask questions in the House (Mersham, Theunissen, \& Peart, 2009). An increasingly-used indirect lobbying tactic is to stay in the background and support experts and proponents to speak up in the media (ibid.).

Another, more secretive, tactic is astroturfing, which Hager (2012) described as a 'manipulative public relations' practice (p. 212). Astroturfing involves manufacturing supporters, such as creating false community support groups, secret employment of seemingly independent scientists, spying on opponents and attacking opposing experts (ibid). Astroturfing is a controversial tactic often used in the USA, which aims to influence decision makers by making them believe there is overwhelming public support for a particular position, when in reality it is fabricated by the lobbying business (Fitzpatrick \& Palenchar, 2006). According to Mersham, Theunissen and Peart (2009) astroturfing should be avoided. 'It is deemed as highly unethical because it is misleading and thus little more than propaganda' (p. 184). In an investigation into public relations 
in the USA, Stauber and Rampton (2004) stated 'even PR practitioners use the term (astroturfing) to deride their competitors' work' (p.79).

Despite the unethical nature of astroturfing, at least two such campaigns have received publicity in New Zealand. One was a political and media campaign aimed at promoting logging of native forests, and involved the fabrication of a pro-logging campaign by creating a fake pro-logging community group, secretly paying so-called independent scientists employed to support logging, employing spies to report on activities by counter groups, and attacking funding sources of scientists on the other side opposed to logging (Hager 2012). All of this was aimed at gaining favourable media coverage for logging and influencing public opinion. Another example was the benign-sounding Association of Community Retailers, which was in fact set up and funded by Imperial Tobacco, to protest tobacco-related legislation $(\mathrm{Ng}, 2010)$.

\section{Lobbying and the media}

A convenient vehicle for lobbyists to disseminate their political messages is the general media, which is the primary channel for receiving information about decisions and decision makers for most citizens (Stromback, 2008), but as Callaghan and Schnell (2001) state, the public is often 'at the mercy of the media and other key political agents who meet as combatants in the policy arena and determine how issue debates and policy alternatives will be structured and defined' (p. 183). In determining what is newsworthy, journalists sort through a large amount of information to determine what is likely to be considered most relevant by citizens (Louw, 2010). It is in the interest of lobbyists to attempt to influence what is being reported and how it is framed (Hager, 2012). Many public relations practitioners are skilled in media and understand how to frame issues to meet news values, (Comrie, 2002). Lobbyists may influence politicians by getting the media to report their issue in a way advantageous to their cause (Thompson \& John, 2007).

A recent trend helping lobbyists push their messages is the commercialisation or private control of the news media where revenue is largely reliant on advertising, described as 'the great crisis in journalism today' (McChesney, 2012, p. 683). The need for news organisations to make ever-increasing profits to satisfy shareholders, combined with ownership of media organisations shifting from a multitude of different companies to a handful of media corporations, has seen a decline in both the quantity and quality of journalism (McChesney, 2012). In the period between 2000 and 2012, McChesney (2012) estimates the amount of both labour and resources going into producing new stories in the USA had dropped by 30 percent, blaming commercialisation for the number of publications decreasing, as are the number of reporters (ibid.). The watchdog role of media is weakened and the decline in newsroom staff negatively impacts on the 
investigation and generation of original news stories, resulting in an increase in 'unfiltered public relations' being reported as news (p. 686). McChesney contends that 'slashing' journalism staff allows illegal activities of lobbyists to go undetected, and culprits, such as lobbyists Jack Abramoff, who was sentenced to six years in prison for conspiracy to bribe public officials, mail fraud and tax evasion, would go undetected and unreported in future (p. 685).

In New Zealand, public relations practitioners 'far outnumber the news organisations and their shrinking staffs' (Hager, 2012, p. 212). In addition, public relations practitioners are generally more experienced than their reporting counterparts (Comrie, 2002). As an example of the success of public relations practitioners to get their messages picked up by the media, research by Comrie in 1997 showed that of 66 press releases issued by two New Zealand Crown Health Enterprises, 54 were published by media with 97 stories resulting (Comrie, 1997). Another study of 674 newspaper articles published during the controversial debate over allowing generic engineering found two-thirds omitted contextual information on how the journalist received the quotes or information, such as a media release, news conference, interview (Rupar, 2006). The study also found that business sources were more likely to have no contextual information 'had less-questioned access to the news' than other sources (p. 137). Rupar called for more precision in journalism (a term credited to Myer, 1991) by including in news stories the motive and method of the sources. Her study indicated the reason for giving business groups an unfettered entry into a news story could be the result of business groups' army of public relations staff who produce wellwritten media releases ready for newspapers to publish without extra effort. If readers are informed that the information came from a media release, they know there are commercial interests at stake and therefore 'factual certainty produces transparency and clarity of news and is relevant for public rebates on important issues in society' (p. 134).

\section{Theoretical foundation: Media framing}

It is understandable that the media keep news items concise by taking shortcuts in the words used to describe events or sources, and these selected words can help frame understanding of the context of the news articles (Haskell, 2011). The media framing theory posits that news articles give contextual clues to help the public evaluate the subjects of the articles, but these contextual cues can promote interpretations for the issues and events being covered and, thereby, influence public opinion (Haskell, 2011). How the media frames a news story can have a negative effect by eliminating voices and weakening arguments and this allows the media to 'frame issues in ways that favour a particular side without showing explicit bias', (Tankard, 2001, p. 95). The power of framing stems from media defining a debate without the public realising they are being 
influenced, and an example given by Tankard was the reporting of the Watergate case, when public opinion shifted against US President Nixon after the media moved from describing it as the 'Watergate caper' to a "national political scandal at the highest level"' (p. 97). While framing is necessary in reporting, Haskell (2011) states these should be neutral, which includes how sources in the story are described.

This research project looked at how the New Zealand media describe the sources of information, when the source is in reality a lobby group. This goes to the foundation writing rules for journalists, who are taught to adequately identify sources and their credentials or agendas for being included in the story (Hannis, 2014; Reuters, 2015). It is also enshrined in most media codes of ethics (such as EPMU, 2011; International Federation of Journalists, 1986; Society of Professional Journalists, 2014) that instil on professional journalists to strive to find the truth, and not hide relevant information from their audiences.

As discussed in the literature review above, lobbying is a common practice in democracies that foster differing viewpoints, but it becomes suspect when it employs tactics that keep them out of the public view and the policymakers are led to think the general public, not personal-interest groups, hold these viewpoints. This is where the media framing and transparency is involved - in putting the spotlight on the lobby activities so the public knows who is behind each viewpoint, and their respective political or commercial agendas. It is only with this full knowledge that news audiences can adequately weigh up differing opinions and decide which to support, and that policymakers can assess how much public support, rather that partisan support, is displayed. When two opposing sides try to reframe their argument with positive verbiage, citizens should be able to rely on the news media to put each side in context. Journalists and the news media are the ones who accurately describe a group, rather than clouding it with euphemisms or leaving them invisible. This research inspected how the media frames lobbyists in news stories and whether or not they accurately describing lobbyists, or allowed them to remain camouflaged in the background. The research used content analysis to analyse stories produced by the two major newspaper/online news services and used interviews to gain viewpoints from two independent observers of New Zealand Parliament.

\section{Research method}

This research used traditional content analysis of news articles published over a three-month period between January 1 and March 31, 2015, on the websites of the two largest newspaper organisations in New Zealand, which published 21 ( 80 percent) of the country's daily newspapers at the time of the sampling. The full text of the articles to be analysed were sourced from Fairfax New Zealand's Stuff website (stuff.co.nz), which draws news from its ten daily newspapers, 
two weekend papers, and 65 regional and specialist newspapers; and New Zealand Media and Entertainment's (NZME) The New Zealand Herald's website (herald.co.nz), which draws from its two weekend newspapers, six daily newspapers, and 20 regional newspapers. Both websites were searched using the advanced Google search option, which allows for date parameters to be set. In order to ensure the research captured only the work of reporters in New Zealand, the sample excluded letters to the editor, articles written by overseas journalists and republished in New Zealand and opinion pieces written by non-journalists.

The sample was 817 news articles that mentioned any of the 20 prominent New Zealand lobby groups, which representing a mixture of business and public interest causes. The analysis determined how frequently these groups were cited, and what descriptors, if any, were applied to them in the news stories.

The second stage was interviews with two people from differing industries who have observed New Zealand parliament and lobbying over several decades. The first was an academic scholar who has observed Parliament leadership since the 1960s, Dr Margaret Hayward. She had worked within Parliament for many years, before turning to researching it. The second interview was with former senior journalist and director since 1984 of an influential Wellington-based media management public relations company, Karen Barnsley. The interview participants were given the results of the content analysis and asked their viewpoint.

\section{Results}

\section{Content analysis results}

A total of 817 news stories mentioning one of the 20 selected lobby groups were published on the websites (Table 1). Of those, 458 were published on Stuff and 359 on The New Zealand Herald website. Of the 817 articles, 90 percent $(\mathrm{N}=739)$ did not contain any descriptors to describe or label the lobby group, and used only the group's name. In only 10 percent $(\mathrm{N}=78)$ was any kind of label used to describe the group at all. In only 3 percent $(\mathrm{N}=21)$ was the label lobby applied to identify the group as a lobby group.

A third of the news articles $(\mathrm{N}=252)$ reported the groups' political message, an indirect method of getting their side of an issue to politician and policy makers. Only 8 percent $(\mathrm{N}=21)$ of these articles used the word 'lobby' and only 18 percent $(\mathrm{N}=46)$ used any descriptor at all. Looking at it the other way, the results showed 82 percent of articles expounding the lobbyist message did not declare their interest or agenda.

Looking at the 78 articles in which any descriptor labels were used, lobby was the most often used label at 27 percent $(\mathrm{N}=21)$, and the group that most often was given the descriptor lobby by the media was climate change group Generation Zero, with half of the 16 articles written about them using the term. Other terms 


\section{Table 1: Descriptors applied to 20 selected lobby groups, 2016}

\begin{tabular}{|c|c|c|c|c|c|c|c|c|c|c|c|c|c|}
\hline Lobby group & 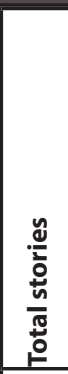 & 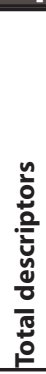 & 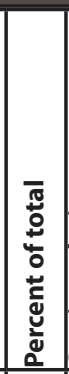 & 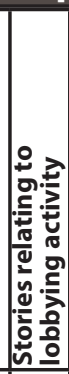 & 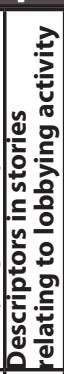 & 증 & 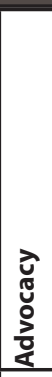 & 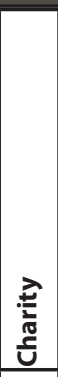 & 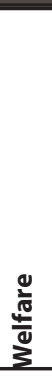 & 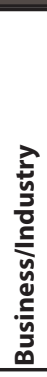 & 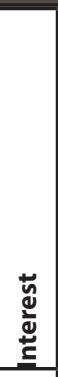 & 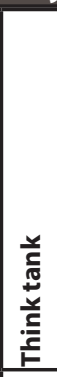 & Others (specify) \\
\hline $\begin{array}{l}\text { Federated } \\
\text { Farmers }\end{array}$ & 273 & 3 & 1.1 & 58 & 2 & 1 & - & - & - & - & - & - & $\begin{array}{l}\text { Influential organisation, } \\
\text { farmer body }\end{array}$ \\
\hline $\begin{array}{l}\text { Business New } \\
\text { Zealand }\end{array}$ & 4 & 0 & 0 & 4 & 0 & - & - & - & - & - & - & - & \\
\hline $\begin{array}{l}\text { Chamber of } \\
\text { Commerce }\end{array}$ & 151 & 4 & 2.7 & 42 & 3 & - & - & - & - & 1 & - & - & $\begin{array}{l}\text { Voice of business, business } \\
\text { leaders, stakeholder }\end{array}$ \\
\hline EMA & 15 & 3 & 20 & 2 & 1 & - & - & - & - & - & - & - & \\
\hline $\begin{array}{l}\text { Food and Gro- } \\
\text { cery Council }\end{array}$ & 9 & 2 & 33.3 & 3 & 1 & - & - & - & - & - & 1 & - & Industry chiefs \\
\hline Straterra & 1 & 1 & 100 & 1 & 1 & - & - & - & - & 1 & - & - & \\
\hline $\begin{array}{l}\text { The New Zea- } \\
\text { land Initiative }\end{array}$ & 10 & 9 & 90 & 7 & 6 & 1 & - & - & - & - & - & 8 & \\
\hline $\begin{array}{l}\text { NZ Retailers } \\
\text { Association }\end{array}$ & 5 & 1 & 20 & 4 & 1 & - & - & - & - & - & - & - & Retailers \\
\hline $\begin{array}{l}\text { Hospitality } \\
\text { New Zealand }\end{array}$ & 18 & 2 & 11.1 & 7 & 2 & - & - & - & - & - & - & - & $\begin{array}{l}\text { Hospitality leaders, part } \\
\text { of alcohol industry }\end{array}$ \\
\hline $\begin{array}{l}\text { Taxpayers } \\
\text { Union }\end{array}$ & 26 & 4 & 15.4 & 25 & 4 & 3 & - & - & - & - & - & - & Watchdog group \\
\hline Greenpeace & 22 & 2 & 9 & 11 & 0 & - & - & - & - & - & - & - & $\begin{array}{l}\text { Not eco terrorists, } \\
\text { environmental group }\end{array}$ \\
\hline Grey Power & 40 & 1 & 2.5 & 21 & 1 & 1 & - & - & - & - & - & - & \\
\hline $\begin{array}{l}\text { Forest and } \\
\text { Bird }\end{array}$ & 11 & 2 & 18 & 4 & 2 & - & - & - & - & - & - & - & $\begin{array}{l}\text { Conservationists, } \\
\text { environmental group }\end{array}$ \\
\hline SPCA & 130 & 6 & 4.6 & 6 & 1 & - & - & 2 & 3 & - & - & - & Animal activists \\
\hline $\begin{array}{l}\text { Environmen- } \\
\text { tal Defence }\end{array}$ & 11 & 5 & 45.5 & 10 & 5 & - & - & - & - & - & - & - & \begin{tabular}{|l|} 
Environmental group (4), \\
environmental community
\end{tabular} \\
\hline $\begin{array}{l}\text { Sensible } \\
\text { Sentencing } \\
\text { Trust }\end{array}$ & 42 & 5 & 11.9 & 24 & 2 & 2 & 1 & - & - & - & - & - & $\begin{array}{l}\text { A group wanting tougher } \\
\text { penaltiesfor crime, child } \\
\text { exploitation and sexual } \\
\text { abuse advocates }\end{array}$ \\
\hline Family First NZ & 16 & 3 & 18.8 & 3 & 0 & 2 & - & - & - & - & - & - & Kill joys \\
\hline Paw Justice & 8 & 8 & 100 & 1 & 1 & - & 3 & 1 & 4 & - & - & - & \\
\hline $\begin{array}{l}\text { Generation } \\
\text { Zero }\end{array}$ & 16 & 11 & 75.0 & 13 & 9 & 8 & - & - & - & - & - & - & $\begin{array}{l}\text { Climate change group, } \\
\text { environmental groups, } \\
\text { cycleways supporter }\end{array}$ \\
\hline ASH & 9 & 6 & 66.7 & 6 & 4 & 3 & 1 & - & - & - & - & - & $\begin{array}{l}\text { Anti-smoking group, } \\
\text { anti-smoking purists }\end{array}$ \\
\hline Total & 817 & 78 & $9.6 \%$ & 252 & 46 & 21 & 5 & 3 & 7 & 2 & 3 & 8 & 31 \\
\hline
\end{tabular}


used for this group were climate change group, environmental group and cycleway supporters. Other groups to receive the lobby group label were: the Taxpayers Union ( $\mathrm{N}=3)$, Action on Smoking and Health $(\mathrm{N}=3)$, Sensible Sentencing Trust $(\mathrm{N}=2)$, Family First New Zealand $(\mathrm{N}=2)$, Grey Power $(\mathrm{N}=1)$, The New Zealand Initiative $(\mathrm{N}=1)$ and Federated Farmers $(\mathrm{N}=1)$. The next most frequently used label was think tank, which was used exclusively in the eight articles about New Zealand Initiative. Interestingly, this is the term the group called itself in its media releases. The description welfare group and charity group was used 14 percent $(\mathrm{N}=11)$ for Society for the Prevention of Cruelty to Animals (SPCA) and 5 percent $(\mathrm{N}=4)$ for Paw Justice. Again, these are terms the animal protection groups use themselves in their media statements.

The three powerful lobby groups that generated large amounts of media stories during this sample period received few or no descriptors at all. Of the 273 stories that included a mention of farming lobby group Federated Farmers only 1 percent $(\mathrm{N}=3)$ included a descriptor: lobby, influential organisation and farmer body. Of the 151 stories on the Chamber of Commerce only 3 percent $(\mathrm{N}=4)$ used a label: voice of business, business leaders, stakeholder and business group. Of the 130 stories on the SPCA, only 5 percent $(\mathrm{N}=6)$ included a descriptor: charity, welfare, and animal activist.

\section{Interview results}

Dr Margaret Hayward first observed New Zealand lobbying in 1967 when it was 'normally a whisky under the arm' and nice 'pally talk' to the party leaders or involved minister, but she recognised that it has become more sophisticated and more centred on the media. Based on her observations, she was not surprised by the results of the content analysis, but was alarmed at the media practice. She said from a public accountability viewpoint it was dangerous for the media to skip over the step of properly identifying a key player in a news story. She estimated most online news consumers would be unaware that these groups were pressure groups, and most citizens were not aware of lobbying occurring in New Zealand:

The situation is deceitful. I don't think the journalists are deliberately being deceitful, although I have suspicious about the lobbyists, but overall the picture is that people are deceived.... I'm not happy about anonymity. They hide behind the fact most people think these groups are speaking out of goodwill, and not because they want a privileged position or want legislation that will give them a competitive advantage.

Karen Barnsley, director of a public relations company specialising in media management, acknowledged that some organisations might prefer to be able to give media statements without being identified as having a vested interest in an 
issue, but she pointed out that this was unfair to organisations on the other side of the controversy or issue. She said if a news article gave conflicting opinions where one side was identified as a lobby group and the other side was not identified as such, it benefitted one side and not the other.

\section{Discussion}

This study showed most (90 percent) news articles did not describe lobby groups' agenda in any way, simply using the groups' formal name. Only onetenth of the 817 news stories used any kind of label to describe the groups' relationship to lobbying. In several cases the labels used by the journalists were simply those provided by the lobby group itself. It is accepted practice for reporters to provide a designation or descriptor for the individuals or organisations they cite in news stories (Hannis, 2014, p. 207), but this sample indicated they are not doing so. It is apparent from the results of the content analysis that lobby groups are able to disseminate their messages without the public aware of their agendas. Without this clear description in news stories, the public are being left in the dark and not being given the information with which to make well-informed decisions. This has an important implication for democracy, as without the full information, the public may not be aware of the motives behind some political decisions.

As example, it appears from the research that an organisation such as the powerful Federated Farmers, which was given a label in only 1 percent of the 273 stories that included a mention of them, can act without the public being aware or reminded of their motivations for commenting on and trying to influence government policy for the commercial benefit of their members. Without this understanding of Federated Farmers' role, the public could easily think they are simply an agriculture-related company. To report only the name of an organisation and no further descriptors means that audiences are left to draw their own conclusions about what the group is about and what its motivations are from the content of the story, or sometimes even from just the organisation's name. As an example, the Taxpayer's Union, which was labelled as a lobby group in only three of the 26 stories, has a name that indicates to the public that it represents taxpayers. While this may be the group's intention, without further investigation, or information from the media, the public will be unaware that it is a lobby group for a right wing political movement. One news story descriptor supported this misunderstanding by labelling them a watchdog group. Similarly, the Christian moral organisation Family First New Zealand received only three descriptors in the 16 stories written about them. While two of these were lobby group, the third descriptor, kill joys, was perhaps more in keeping with some people's views of its activities.

It is significant that almost one-third of the articles mentioning the lobby 
groups was specifically on the message they wanted to get across to the policy makers. This is using the media as a vehicle to possibly sway decision-making. The concern is that a vast majority of these ( 82 percent) on-message news articles omitted describing the lobby group as such, thereby possibly camouflaging the commercial interest of the viewpoint.

It is beyond the scope of this study to determine why reporters are failing to provide such basic information in their news reporting. It is possible that some become so familiar with the groups they deal with that they assume the public also knows this. It is also possible that with the commercial pressures and downsizing of newsrooms, as outlined by McChesney (2012), reporters simply do not have the time or the resources to properly investigate the groups they are dealing with, especially if the information is mainly from a media release from the group (Comrie, 1997). It is also concerning to see an almost complete absence of the lobby group label being applied to the influential, big business lobby groups such as Federated Farmers, Business New Zealand and the Chamber of Commerce.

These results mirror the lack of journalism precision and transparency shown in Rupar's 2006 analysis of GE-debate news articles whereby most articles omitted information on the journalists' method of newsgathering (such as the information was sourced from media releases, websites, interviews, or media conferences). Similar to our study, Rupar also found that newsmakers representing big business interests were given less transparent context in the story compared to other groups.

The seasoned Parliamentary observer Dr Margaret Hayward describes the media practice of not identifying lobby groups when giving them publicity as alarming and dangerous from the point of view of an informed public. She likened it to journalists giving lobby groups anonymity. This lack of transparency also affects other groups who are trying to make their viewpoint heard. As pointed out by public relations director Karen Barnsley, it could be unfair when a news story reports conflicting opinions by pressure groups, but only one is identified as a lobbyist and the other group is not.

\section{Conclusion}

This study originally set out to explore if the media used lobbyist rather than other euphemisms to describe political pressure groups. It was a surprising result to find the media was not using any term to describe them, leaving it up to the readers to make assumptions as to the motives and agenda of those quoted in a news article. The nature of lobbying is such that it is advantageous for them to be able to covertly persuade policy makers - away from the public view and public scrutiny. Tactics such as astroturfing are considered unethical and are specifically to hide the fact that it is lobbyists who are putting pressure on policy makers. By not fully identifying lobby groups', journalists are helping 
downplay their agendas, instead of showing their true aim of trying to pressure government for the benefit of specific businesses or industries.

The media often is accused of framing a news story in a certain way by the words and descriptors they use, but in this instance the media is framing-byomission, which downplays the significance of the lobby groups' motives. This research did not look at the reason behind the lack of descriptors, but the finding that several labels used in news stories were simply those supplied by the pressure groups themselves lead to an assumption a contributing factor is the current trend toward a more commercialised media and the resulting downsizing of newsroom staff. In other words, the journalists have less time to adequately put context into the news articles. The absence of transparency is particularly alarming now that lobbying seems to be played out more through the media rather than directly in Parliament itself. The research in this project indicates that the media are failing to inform their audiences, and, as a result, audiences may be in the dark about which groups are lobbyists and which are not. This has implications for the democratic process whereby citizens may not be aware which lobby groups are trying to influence lawmakers and what laws they want changed.

The intent of this study was to explore how the news media frame lobbying activities in New Zealand. It is apparent from the results that framing-by-omission is in practice and thereby the media is helping lobbyists keep their motives out of the glare of news media spotlight. This study is one of the few research projects on New Zealand media treatment of lobbyists, and clearly indicates that with 90 percent of stories omitting any description of lobby groups, and 97 percent avoiding the word lobbyist completely, the news consuming public could feel uninformed. This is particularly significant in New Zealand which, unlike many other Western countries, lacks a legal register or code of ethics for lobbyists. In summary, it appears that inaction by both the media and Parliament allow hired pressure groups to stay camouflaged when trying to influence New Zealand policy makers on behalf of their clients.

\section{References}

Australian Government Department of Prime Minister and Cabinet (2016). Who is on the register? Retrieved from http://lobbyists.pmc.gov.au/who_register_clients.cfm

Berg, K. T. (2012). The ethics of lobbying: Testing an ethical framework for advocacy in public relations. Journal of Mass Media Ethics: Exploring questions of media morality, 27(2), 97-114.

Callaghan, K. \& Schnell, F. (2001). Assessing the democratic debate: How the news media frame elite policy discourse. Political Communication 18, 182-212.

Center for Responsive Politics (2017). Lobbying database. Washington, DC: OpenSecrets. Retrieved from https://www.opensecrets.org/lobby/

Comrie, M. (1997). Media tactics in New Zealand's Crown Health Enterprises. Public Relations Review, 23(2), 161-176. 
Comrie, M. (2002). Spin in the news. In J. McGregor \& M. Comrie (Eds.) What's news? Reclaiming Journalism in New Zealand (pp. 158-172). Palmerston North, New Zealand: Dunmore Press.

Crang, N. (2013). Lobbying disclosure bill fails but transparency encouraged. Duncan Cotterill Law Firm. Retrieved from https://goo.gl/KKqoBh

EPMU (2017). Journalism code of ethics. EPMU. Auckland, New Zealand: NZ Amalgamated Engineering, Printing \& Manufacturing Union Inc. Retrieved from www. epmu.org.nz/journalist-code-of-ethics

Fang, L., (2014, 10-17 March). Where have all the lobbyists gone? The Nation. Retrieved from www.thenation.com/article/shadow-lobbying-complex

Fitzpatrick, K., \& Palenchar, M. J. (2006). Disclosing special interests: Constitutional restrictions on front groups. Journal of Public Relations Research, 18, 203-224.

Greisser, P. (2103). Behind the scenes in Brussels: An analysis of the lobbyists and their activities in a European context. Unpublished master's thesis, University of Amsterdam, Amsterdam, The Netherlands. Retrieved from www.oepav.at/de/beirat/

Hager, N. (2012). Twenty-five ways to have better journalism. In M. Hirst, S. Phelan \& V. Rupar (Eds.), Scooped: The politics and power of journalism in Aotearoa New Zealand (pp. 211-226). Auckland, New Zealand: AUT Media.

Hager, N. (2014). Dirty politics: How attack politics is poisoning New Zealand's political environment. Nelson, NZ: Potton \& Burton.

Hannis, G. D. (2014). News writing. In G. D. Hannis (Ed.), Intro: A beginner's guide to journalism in 21st-century Aotearoa/New Zealand (pp. 199-217). Lower Hutt, NZ: New Zealand Journalists Training Organisation.

Harris, P. (2002). Defining and demystifying lobbying. Psychology and Marketing, 19(12), 987-992.

Harris, P., \& McGrath, C. (2012). Political marketing and lobbying: A neglected perspective and research agenda. Journal of Political Marketing, 11(1-2), 75-94.

Haskell, D. M. (2011). What we have here is a failure to communicate: Same-sex marriage, evangelicals, and the Canadian news media. The Journal of Religion and Popular Culture, 23(3), 311-329.

Hogan, J., Chari, R., \& Murphy G. (2011). Regulating Australia’s lobbyists: coming full circle to promote democracy? Journal of Public Affairs, 11(1), 35-48.

International Federation of Journalists (1986). IFJ declaration of principles on the conduct of journalists. Brussels, Belgium: IFJ International Federation of Journalists. www. ifj.org/about-ifj/ifj-code-of-principles/

Kent, D. (1998). The joy of lobbying: Campaigning to influence government decisions and public attitudes. Wellington, NZ: Gateway Lobbyskills.

Krsmanovic, D. (2014). A law and economics analysis of lobbying regulation: Towards an optimal structure through the cost indicator index. Erasmus University Rotterdam. Available at SSRN: https://ssrn.com/abstract=2669345

Lobbying Disclosure Bill. (2012). Evidence and submissions. Retrieved from https:// goo.gl/a8mDx6.

Louw, E. (2010). Political media practice: An outline. In P.E. Louw (Ed.), The media and political process (pp. 47-74). London, UK: Sage.

Mallard, T. (2003, November). Lobbying and the government. Speech presented to the Four Winds Communications seminar, Wellington, New Zealand. Retrieved from: www.beehive.govt.nz/speech/lobbying-and-government

Malone, M. M. (2004). Regulation of lobbyists in developed countries: Current rules and practices. Dublin, Ireland: National University of Ireland. 
McChesney, R. W. (2012). Farewell to journalism? Journalism Studies, 13(5-6), 682-694. Mersham, G., Theunissen, P., \& Peart, J. (2009). Public relations and communications management: An Aotearoa/New Zealand perspective. North Shore, NZ: Pearson.

Meyer, P. (1991). The new precision journalism. Bloomington, IN: Indiana University Press.

Ng, K. (2010). Astrotobacco. OnPoint blog. Retrieved from http://publicaddress.net/ onpoint/astrotobacco/

Parliament. (2013). Lobbying Disclosure Bill report. Government Administration Select Committee. Retrieved from www.parliament.nz/en-nz/pb/legislation/ bills/00DBHOH_BILL11278_1/lobbying-disclosure-bill

PRINZ. (2017). About PRINZ. PRINZ. Wellington, New Zealand. Retrieved from www. prinz.org.nz/Category?Action=View\&Category_id $=159$

Reuters News Service (2017). Essentials of Reuters sourcing. Handbook of journalism. Reuters: Retrieved from http://handbook.reuters.com/index.php?title=The_Essentials of_Reuters_sourcing

Rupar, V. (2006) How did you find that out? Transparency of the newsgathering process and the meaning of news, Journalism Studies, 7(1), 127-143, DOI: $10.1080 / 14616700500450426$

Society of Professional Journalists (2014). SPJ Code of Ethics. Indianapolis, IN: SPJ. http://www.spj.org/ethicscode.asp

Stauber, J., \& Rampton, S. (2004). Toxic sludge is good for you: Lies, damn lies and the public relations industry. London, UK: Constable \& Robinson.

Stromback, J. (2008). Four phases of mediatization: An analysis of the mediatization of politics. The International Journal of Press/Politics, 13, 228-246.

Tankard, J. W. Jr. (2001). The empirical approach to the study of media framing. In S. D. Reese, O. H. Gandy Jr., and A.E Grant (Eds.), Framing public life: Perspectives on media and our understanding of the social world. (pp. 95-105). Mahwah, NJ: Lawrence Erlbaum.

Thomson, S. \& John S. (2007). Public affairs in practice: A practical guide to lobbying. London \& Philadelphia: Kogan Page.

United Kingdom Public Affairs Council (2014). Definition of Lobbying. Retrieved from www.publicaffairscouncil.org.uk/en/resources/lobbying-definition.cfm

Yaeger, H. (2013, October 15). Lobbyists' lobbying group wants a new name - one that doesn't mention lobbying. Washington Post . Retrieved from goo.gl/0VEJ4R

Young, A. (2013, June 17). Speaker allows twice as many lobbyists to get free pass. The New Zealand Herald. Retrieved from www.nzherald.co.nz/politics/news/article. cfm?c id=280\&objectid=10890993

Young, A. (2003). The good lobbyist's guide: A complete handbook for New Zealanders. Auckland, NZ: Exile Publishing.

Zetter, L. (2008). Lobbying: The art of political persuasion. Petersfield, UK: Harriman House.

Dr Catherine Strong is a senior lecturer and Fran Tyler is a tutor in the School of Communication, Journalism and Marketing at Massey University, Wellington, New Zealand.

c.r.strong@massey.ac.nz 